\title{
Magnesium and the metabolic syndrome: a systematic review and meta-analysis
}

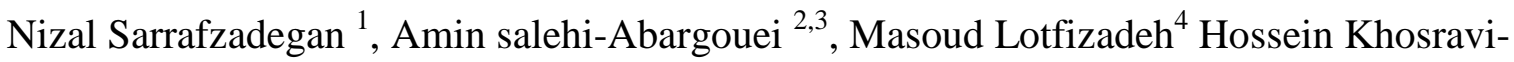 \\ Boroujeni $^{1,5}$ \\ ${ }^{1}$ Isfahan Cardiovascular Research Center, Cardiovascular Research Institute, Isfahan \\ University of Medical Sciences, Isfahan, Iran \\ ${ }^{2}$ Nutrition and Food Security Research Center, Shahid Sadoughi University of Medical \\ Sciences, Yazd, Iran. \\ ${ }^{3}$ Department of Nutrition, Faculty of Health, Shahid Sadoughi University of Medical \\ Sciences, Yazd, Iran. \\ ${ }^{4}$ Community Health Department, Shahrekord University of Medical Sciences, Shahrekord, \\ Iran \\ ${ }^{5}$ School of Medicine and Griffith Health Institute, Griffith University, QLD, Australia
}

Running title: $\mathrm{Mg}$ and metabolic syndrome

\section{Corresponding author:}

Hossein Khosravi Boroujeni, Isfahan Cardiovascular Research Center Cardiovascular Research Institute Isfahan, Iran and School of Medicine and Griffith Health Institute, Griffith University, QLD, Australia

Tel: +61755527820

Email:khosravi_bh@yahoo.com 


\section{ABSTRACT}

Purpose: Reduced serum Mg (Mg) concentrations and low intakes of $\mathrm{Mg}$ are proposed to be associated with metabolic syndrome (MetS) and its components or related diseases, including insulin resistance, diabetes mellitus, hypertension, dyslipidemia and cardiovascular diseases. The aim of the present study is to systematically review the published evidence on the association between $\mathrm{Mg}$ intake and its serum concentrations and MetS and if possible to summarize their results using meta-analysis.

Methods: PubMed, ISI Web of Science, Scopus and Google Scholar were systematically searched to identify related articles, which tried to examine the Mg intake and/or its serum concentration in relation to MetS. Fully adjusted Odds Ratios (ORs) of MetS in participants with the highest intake of $\mathrm{Mg}$ compared to those who had the least consumption and the mean difference in serum Mg level between patients with MetS and their controls were extracted for the meta-analysis.

Results: Totally 9 articles with 31876 participants were included in the meta-analysis regarding the association between dietary Mg intake and MetS and 8 studies, which assessed the mean level of serum $\mathrm{Mg}$ in 3487 individuals with and without MetS were also eligible. Our analysis showed that higher consumption of $\mathrm{Mg}$ is associated with lower risk of MetS $(\mathrm{OR}=0$. 73, CI: 0.62, 0.86, $\mathrm{P}<0.001)$, however, we could not find any association between serum Mg and MetS (95\% CI: -0.28, 0.03, P=0. 113).

Conclusion: The present systematic-review and meta-analysis showed a strong inverse association between $\mathrm{Mg}$ intake and MetS, but no relationship was shown between serum $\mathrm{Mg}$ and MetS.

Key words: Dietary Magnesium, Serum Magnesium, metabolic syndrome, diabetes mellitus 


\section{INTRODUCTION:}

The metabolic syndrome (MetS) is highly widespread among developed and developing populations [1]. MetS is characterized as a cluster of risk factors that threats public health, and increases disability, mortality, and health care costs [2]. Based on the Adult Treatment Panel III guidelines, MetS is defined as the presence of 3 or more of the subsequent characteristics: high blood pressure, hyperglycemia, hypertriglyceridemia, low high-density lipoprotein (HDL) cholesterol and abdominal obesity [3]. Regardless of its definition, MetS increases the risk of diabetes and cardiovascular disease [4]. Although the role of dietary ingredients is less understood, dietary components are important in many chronic diseases and it is believed that nutrients are effective in the development of MetS [5].

Magnesium (Mg) is an essential mineral that particularly found in dietary sources such as green leafy vegetables, whole grains, legumes, and nuts [6]. As the second intracellular cation in abundance [7], $\mathrm{Mg}$ is a critical cofactor for hundreds of enzyme reactions, including energy metabolism, protein and nucleic acid synthesis, insulin action and insulin secretion [8, 9]. Previous studies reported that Mg deficiency is frequently (25-47\%) observed in diabetic patients [10]. Rapidly growing evidence suggests that dietary Mg or Mg supplementation has valuable effects, including regulation of systemic inflammation [11] and hypertension [12], modification of lipids [13, 14], glucose and insulin metabolism [15], improvement of insulin sensitivity $[16,17]$ and decreasing the risk of diabetes (6).

Reduced serum Mg concentrations and low intakes of Mg are proposed to be associated with MetS and its components or related diseases such as insulin resistance [18], diabetes mellitus [19], hypertension [8], dyslipidemia [20] and cardiovascular diseases [21]; however data about the association between $\mathrm{Mg}$ status and MetS are conflicting. Some studies have shown a negative association between Mg intake and MetS [22] while others could not reach a significant result [23]. Furthermore, some studies compared the serum Mg concentrations between MetS patients and their controls [24, 25] that was negative [25] or non-significant association [26]; however, some studies have proposed that there may be a positive association between serum Mg concentration and MetS, too [24].

The aim of this study was to systematically review the published evidence on the association between dietary or serum Mg level and MetS and, if applicable, summarize the studies and find the possible sources of using meta-analysis.

\section{MATERIALS AND METHODS:}


Search strategy: We focused on publications considering the association between dietary or serum content of Mg and MetS. PubMed, ISI web of science, Scopus and Google scholar were systematically searched to identify related articles published up to June 2014. The following keywords that were selected from the Medical Subject Headings (MeSH) and other related terms were used for the database search: "Mg" OR "mg*" in combination with "Metabolic Syndrome X" OR "metabolic syndrome" OR "syndrome X". No language or any other limitation was incorporated in our literature search. Reference lists of related articles were considered for other potentially related papers. Titles and abstracts were separately reviewed by two authors (HKB, ASA) to find eligible articles for the present study. Any inconsistency between search results was resolved by discussion with the other authors (NS, ML).

Inclusion criteria: Observational studies published in peer reviewed journals that assessed the association between $\mathrm{Mg}$ intake and MetS, or studies which compared serum levels of $\mathrm{Mg}$ in patients with and without MetS were included in our systematic review.

Exclusion criteria: Studies that examined the association between Mg intake or serum levels of $\mathrm{Mg}$ with MetS in participants with polycystic ovary syndrome (PCOS) [27], cardiac syndrome [28], diabetes mellitus [29-31], morbidly obese individuals [32] were excluded from our study. One study that did not compare the Mg content of the whole diet was also excluded [33].

Data extraction: We extracted all relevant information from eligible articles, including first authors' family name, publication year, MetS definition, study design, participants' gender, age range, geographic location, total sample size, sample size in case and control studies, $\mathrm{Mg}$ intake, Relative Risks (RRs) or Odds Ratios (ORs) of MetS for comparison between highest and lowest category of $\mathrm{Mg}$ intake in models, which had the highest number of adjusted variables in the statistical model. Furthermore, we extracted the mean \pm SD of serum $\mathrm{Mg}$ levels for studies that compared serum Mg levels between participants with MetS patients and their controls. Data extraction and the quality assessment were completed by 2 authors (HKB, ASA) to guarantee equality, and one of the authors entered all of the data (HKB).

Most of the studies presented the serum $\mathrm{Mg}$ or $\mathrm{Mg}$ intake in $\mathrm{mg} / \mathrm{dl}$. In studies in which $\mathrm{Mg}$ concentration was not shown in mg/dl we changed other formats including mg/l [24], mmol/l [26] and meq/l [34] to $\mathrm{mg} / \mathrm{dl}$.

\section{Data analysis}

The ORs and their 95\% confidence intervals (CIs) for comparing the prevalence or the incidence of MetS between groups with highest and lowest Mg intake were used to calculate 
the log OR and its Standard Error (SE) as the effect size for meta-analysis [35]. RRs were considered as ORs when used in meta-analysis because only one study reported relative risks [36]. We calculated OR and its 95\% CI, if a study reported the number of participants based on their Mg consumption strata. Eight studies also compared the mean $\pm \mathrm{SD}$ of serum $\mathrm{Mg}$ level in cases with MetS and their controls [24-26, 34, 37-40] that were used to calculate unstandardized mean difference as effect size to be included in a separate meta-analysis.

The overall effect was derived by using a random effects model, which takes between-study variation into account [35]. Subgroup analysis and meta-regression were incorporated to search about the possible sources of heterogeneity, if needed. Statistical heterogeneity was assessed using Cochran's Q test and I squared [41]. Sensitivity analysis was used to explore the extent to which inferences might depend on a particular study or a number of publications. Publication bias was evaluated by looking over Begg's funnel plots [42]. Formal statistical assessment of funnel plot asymmetry was done by Egger's regression asymmetry test and Begg's adjusted rank correlation test. Statistical analyses were conducted using STATA version 11.2 (STATA Corp, College Station, TX). P values less than 0.05 were considered statistically significant.

\section{RESULTS}

\section{Study characteristics}

Our search retrieved 141 articles of which 19 related articles fulfilled our inclusion criteria. Only one study that compared mean Mg intake between patients with and without MetS was included in our systematic review, but not in the meta-analysis [43]. Another study did not represent data on OR of MetS based on $\mathrm{Mg}$ intake, therefore the authors were asked about data by three Emails separated at least by one week, and the authors could not provide the needed data therefore we also included this article in the systematic review but not in the meta-analysis too [44]. The flow diagram of the study selection process is presented in

\section{Figure 1.}

Among the reviewed articles, 5 were conducted in the United States [43, 45-48], 2 in Greece [34, 37], 2 in Mexico [25, 39], one in Australia [26], China [24], Taiwan [22], Italy [23], Brazil [40] South Korea [49], Saudi Arabia [50] and 3 in Iran [38, 44, 51] (Tables 1 and 2). The participants' age varied from 18 to 90 years and the study sample size varied from 117 to 11686 participants and totally 35363 individuals participated in all studies. Among the 17 studies, one study was conducted entirely by women [36], one study in men [24] and other 
studies reported the association for both genders. Characteristics of included studies in connection with the association between dietary and serum Mg level are presented in Tables 1 and 2 respectively.

Totally 9 articles with 31876 participants were included in the meta-analysis regarding the association between dietary Mg intake and MetS [22, 23, 36, 45, 47, 49-52]. The results of our analysis showed that higher consumption of $\mathrm{Mg}$ is associated with lower risk of MetS $(\mathrm{OR}=0.73$, CI: 0.62, 0.86, $\mathrm{P}<0.001$ ) (Figure 2). However, there was a slight level of heterogeneity between studies (Cochrane $\mathrm{Q}$ test, $\mathrm{P}=0.149$, I-squared $=32.4 \%$ ). When the methodology of included studies was carefully reviewed, we noticed that a study done by McKeown et al [47] used BMI higher than $31 \mathrm{~kg} / \mathrm{m} 2$ for men and $27 \mathrm{~kg} / \mathrm{m}^{2}$ for women as an index for abdominal obesity while other studies defined MetS based on ATP III, therefore we removed this study from our analysis and the heterogeneity significantly decreased (Cochrane $\mathrm{Q}$ test, $\mathrm{P}=0.429$, I-squared $=0.5 \%$ ) while the association remained significant $(\mathrm{OR}=0.78, \mathrm{CI}$ : 0.69, 0.88, $\mathrm{P}<0.001$ ) (Figure 3).

Our preliminary analysis on 8 studies [24-26, 34, 37-40], which assessed the mean serum Mg in 3487 individuals with and without MetS (Figure 4) indicated that serum Mg level in MetS participants is about $0.1 \mathrm{mg} / \mathrm{dl}$ lower compared to normal population (95\% CI: $-0.36,-0.03$, $\mathrm{P}=0.023$ ), but there was a significant heterogeneity among studies (Cochrane $\mathrm{Q}$ test, $\mathrm{P}<0.001$, I-squared=98.5\%). Among included studies two had used IDF [37, 40], one used Chinese Diabetes Society's [24] criteria to define MetS and a study done by Guerrero-Romero [25] had excluded individuals with hypertension and diabetes from the study population. Therefore, these 4 studies were removed from our analysis, but the heterogeneity remained significant (Cochrane Q test, $\mathrm{P}=0.000$, I-squared=96.2\%) (Figure 5). Moreover, removing these articles turned the association between serum levels of $\mathrm{Mg}$ and MetS into nonsignificant one (95\% CI: $-0.28,0.03, \mathrm{P}=0.113$ ). Furthermore, we tried to find the source of heterogeneity using subgroup analysis based on the participant's age, sex, criteria used to define MetS, studies' design and country of origin. We also incorporated meta-regression to examine if publication year, participants' mean age can describe the high level of heterogeneity between the included studies; however, none of these methods were successful to find the source of heterogeneity.

Sensitivity analysis showed that removing none of individual studies trying to examine the association between dietary or blood levels of Mg intake and MetS could significantly change the overall effects. Although Begg's funnen plot showed that the distribution of calculated 
effect sizes, is slightly asymmetric (Figure 6.A), the asymmetry tests did not provide any evidence of publication bias (Begge's test, $\mathrm{P}=0.245$, Egger's test, $\mathrm{P}=0.140$ ). The same result was found for studies investigated the difference between blood levels of $\mathrm{Mg}$ between patients with MetS and healthy population (Begg's test, $\mathrm{P}=0.621$, Egger's test, $\mathrm{P}=0.210$ ) (Figure 6.B).

\section{DISCUSSION}

The present systematic review and meta-analysis showed that increased Mg consumption is associated with lower risk of MetS. Moreover, although the heterogeneity was high, our analyses showed that patients with MetS have lower levels of blood Mg concentrations than healthy controls. Our results provide strong evidence about the favorable protective role of Mg intake in MetS. To the best of our knowledge, there is no systematic review and metaanalysis trying to evaluate the association between $\mathrm{Mg}$ and the MetS.

It must be kept in mind that we could not include two studies [43, 44] regarding the association between dietary $\mathrm{Mg}$ intake and MetS because they did not provide the essential data. However, all these studies have mentioned an inverse association between dietary $\mathrm{Mg}$ intake and MetS in their results. Morrell et al. [43] compared individuals with 2 or more criteria for MetS and participants without any MetS criteria and found a significant difference in their Mg intake (251 vs $269 \mathrm{mg}$ ). Mirmiran et al [44] observed a negative association between dietary Mg and MetS Z-score in obese individuals and high fiber consumers, but this association was not significant in normal weight participants or in low fiber consumption. After adjustment for other covariates, no significant association was found between $\mathrm{Mg}$ intake and MetS. This study indicated that the association between Mg intake and MetS cannot be independent of fiber, $\mathrm{Ca}$ and $\mathrm{K}$, and other nutrients' intake.

Although studies are not entirely consistent about the possible mechanisms, the beneficial effect of $\mathrm{Mg}$ on MetS is related to its potential effect on MetS components. Previous studies demonstrated that low dietary intake of calcium, Mg, and fiber may be associated with insulin resistance and supplementation with $\mathrm{Mg}$ and calcium improved insulin sensitivity [53, 54]. Another study demonstrated that Mg supplementation in elderly patients improved insulin action [53]. Furthermore, it has been shown in a study done by He et al that Mg intake had been associated with all components of MetS [55]. In another study, Mg intake was negatively associated with components of MetS particularly waist circumference, fasting 
blood glucose, and HDL cholesterol level [52]. Mg intake was also inversely linked to the plasma C-reactive protein (CRP) concentration, as it has been hypothesized that a probable positive effect of $\mathrm{Mg}$ intake might be associated with its roles in improving systemic inflammation [36].

A previous meta-analysis showed that Mg supplementation significantly increased serum or plasma Mg levels [56]. The nutrition guidelines of the American Diabetes Association (ADA) recommended $\mathrm{Mg}$ supplementation for diabetic individuals with low serum Mg level [57]. Although, this meta-analysis could not find a strong association between serum $\mathrm{Mg}$ and metabolic syndrome, it has been indicated that low serum $\mathrm{Mg}$ is a significant predictor of dyslipidemia and hypertension [58]. Also, serum Mg was inversely associated with waist circumference and triglyceride (TG) level [59]. It has been revealed that $\mathrm{Mg}$ may regulator lipid level [60], glucose metabolism and insulin activity [61] and also has antioxidant [8], anti-inflammatory [36] and anti-hypertensive [62] effects. Several mechanisms have been suggested to explain the favorable effects of $\mathrm{Mg}$ on features of the MetS or its components. It has been previously suggested that higher $\mathrm{Mg}$ intake and intracellular $\mathrm{Mg}$ was affiliated in insulin stimulation and influence insulin secretion $[16,63]$ by preserving pancreatic $\beta$-cell function via its consequence on calcium homeostasis and oxidative stress [8]. Moreover, $\mathrm{Mg}$ is necessary for the stimulation and transcription of some enzymes and nuclear proteins that are participated in the glycolytic pathway, Krebs cycle, and release of insulin. Besides, the insulin function is completely dependent on $\mathrm{Mg}$, as it is responsible for the activation of the $\beta$-subunit of the insulin receptor, and the motivation of substrates and proteins in the insulinsignalling pathway [64]. It also regulates cellular glucose metabolism via its role as a cofactor [65].

Similarly, Mg acts as a co-factor for several critical enzymes involving lipid metabolism. Mg has been reported to raise HDL and reduce LDL cholesterol and TG via restraining the action of lecithin cholesterol acyltransferase (LCAT) [66] and HMG-CoA reductase and increasing lipoprotein lipase (LPL) activity [67]. It has been assumed that Mg, in the intestine, by forming an un-absorbable soap with fatty acids and cholesterol, can decrease their absorption, reduce energy intake from the diet and may have advantages for weight maintenance because of this capability [68].

Several pathways have been associated with the antihypertensive effects of Mg. Initially, Mg as a calcium antagonist, inhibits the intracellular calcium mobilization [62]; moreover, by 
means of motivating the action of $\mathrm{Na}-\mathrm{K}$ ATPase or rising sodium excretion in urine, reduces the unfavorable effect of sodium [62]. Furthermore, it reduces catecholamines release [62] and improve systemic inflammation [36].

Serum $\mathrm{Mg}$ is the most common test for assessing $\mathrm{Mg}$ status and it is valuable for clinical purpose, such as rapid assessment of critical changes in Mg status [69]. However, it should be noted that $\mathrm{Mg}$ is an intracellular cation and only one percent of $\mathrm{Mg}$ is in the extra-cellular fluid, therefore only about $0.3 \%$ of total body $\mathrm{Mg}$ is found in the serum. Therefore, some researchers have been considered serum mg levels as a poor indicator of body magnesium status [70]. Moreover, in some people with chronic magnesium deficiency who have deficient body Mg, their serum levels might be within the normal range [69]. It could be a possible reason for not finding a significant association between serum $\mathrm{Mg}$ and MetS in the current study. Serum $\mathrm{Mg}$ levels are higher in vegetarians and vegans (in comparison with omnivorous), after endurance exercises and also during the third trimester of pregnancy [71]. By the way, because serum $\mathrm{Mg}$ measurement is feasible and inexpensive, serum $\mathrm{Mg}$ concentration is still used as a standard method for assessing the Mg status in patients [72].

The present study has several limitations that should be considered. We could find only one prospective cohort study, which was trying to find the association between Mg intake and MetS risk and other included studies were cross-sectional in design. All included studies, which tried to compare serum levels of Mg between MetS patients and healthy controls, were case-control in design. It's well known that retrospective studies are prone to recall bias; therefore prospective studies trying to find these associations are strongly recommended.

Moreover, in the analysis of Mg intake and MetS risk, although we used the highest adjusted model, most of the studies could not control the dietary factors that are associated with MetS and it is difficult to entirely separate the effect of $\mathrm{Mg}$ from other dietary nutrients such as calcium, potassium and fiber.

Finally, our analysis on the mean serum level of $\mathrm{Mg}$ in individuals with and without MetS demonstrated a significant heterogeneity among studies and we could not find the possible source of heterogeneity in several subgroup analyses and meta-regression.

\section{Conclusions}

The present systematic-review and meta-analysis showed a strong inverse association between Mg intake and MetS. However, our results about the relationship between serum 
$\mathrm{Mg}$, as a measure of body Mg, and MetS were highly heterogeneous. Therefore, our results should be discussed with more caution. Assessing the body Mg with a better indicator of body storage such as magnesium retention test that shows the stored body Mg might reveal more accurate result.

\section{AUTHORS CONTRIBUTION}

HKB, ASA, ML and NS contributed in conception, design, statistical analyses, data interpretation and manuscript drafting. HKB and ASA contributed in database search, and data extraction. All authors contributed in preparing and approval of the final manuscript for submission.

\section{Conflict of interest}

The authors declare no conflict of interest.

\section{REFERENCES:}

1. Cameron AJ, Shaw JE, Zimmet PZ: The metabolic syndrome: prevalence in worldwide populations. Endocrinol Metab Clin North Am 2004; 33:351-574.

2. Appels CW, Vandenbroucke JP, Hoofnagle JH, Barzel US, Spitzer J, Adams KF, Schatzkin A, Leitzmann MF: Overweight, obesity, and mortality. N Eng/ J Med 2006; 355:2699-2701.

3. Detection EPO: EVALUATION, AND TREATMENT OF HIGH BLOOD CHOLESTEROL IN ADULTS. Executive summary of the third report of The National Cholesterol Education Program (NCEP) Expert panel on detection, evaluation, and treatment of high blood cholesterol in adults (Adult Treatment Panel III). Jama 2001; 285:2486-2497.

4. Ford ES: Risks for All-Cause Mortality, Cardiovascular Disease, and Diabetes Associated With the Metabolic Syndrome A summary of the evidence. Diabetes care 2005; 28:17691778.

5. Khosravi-Boroujeni H, Sarrafzadegan N, Mohammadifard N, Alikhasi H, Sajjadi F, Asgari S, Esmaillzadeh A: Consumption of Sugar-Sweetened Beverages in Relation to the Metabolic Syndrome among Iranian Adults. Obesity Facts 2012; 5:527-537.

6. Saris N-EL, Mervaala E, Karppanen H, Khawaja JA, Lewenstam A: Magnesium: an update on physiological, clinical and analytical aspects. Clin Chim Acta 2000; 294:1-26.

7. López MJ, Sánchez CM, Culebras FJ: Magnesium: metabolism and requirements]. Nutr Hosp 1997; 12:4-14.

8. Barbagallo M, Dominguez LJ, Galioto A, Ferlisi A, Cani C, Malfa L, Pineo A, Busardo A, Paolisso G: Role of magnesium in insulin action, diabetes and cardio-metabolic syndrome X. Mol Aspects Med 2003; 24:39-52.

9. $\quad$ Elin RJ: Magnesium metabolism in health and disease. Dis Mon 1988; 34:166-218.

10. de Lourdes Lima M, Cruz T, Pousada JC, Rodrigues LE, Barbosa K, Canguçu V: The effect of magnesium supplementation in increasing doses on the control of type 2 diabetes. Diabetes care 1998; 21:682-686. 
11. Song $\mathrm{Y}$, Li TY, van Dam RM, Manson JE, Hu FB: Magnesium intake and plasma concentrations of markers of systemic inflammation and endothelial dysfunction in women. Am J Clin Nutr 2007; 85:1068-1074.

12. Guerrero-Romero $F$, Rodríguez-Morán $M$ : The effect of lowering blood pressure by magnesium supplementation in diabetic hypertensive adults with low serum magnesium levels: a randomized, double-blind, placebo-controlled clinical trial. J Hum Hypertens 2008; 23:245-251.

13. Rasmussen HS, Aurup P, Goldstein K, McNair P, Mortensen PB, Larsen O, Lawaetz H: Influence of magnesium substitution therapy on blood lipid composition in patients with ischemic heart disease: a double-blind, placebo controlled study. Arch Intern Med 1989; 149:1050-1053.

14. Altura BM, Altura BT: Magnesium in cardiovascular biology. Cell Mol Biol Res 1995; 2:347359.

15. Nadler JL, Buchanan T, Natarajan R, Antonipillai I, Bergman R, Rude R: Magnesium deficiency produces insulin resistance and increased thromboxane synthesis. Hypertension 1993; 21:1024-1029.

16. Guerrero-Romero F, Tamez-Perez H, Gonzalez-Gonzalez G, Salinas-Martinez A, MontesVillarreal J, Trevino-Ortiz J, Rodriguez-Moran M: Oral magnesium supplementation improves insulin sensitivity in non-diabetic subjects with insulin resistance. A double-blind placebo-controlled randomized trial. Diabetes Metab 2004; 30:253-258.

17. Rodríguez-Morán $M$, Guerrero-Romero F: Oral Magnesium Supplementation Improves Insulin Sensitivity and Metabolic Control in Type 2 Diabetic Subjects A randomized doubleblind controlled trial. Diabetes care 2003; 26:1147-1152.

18. McCarty MF: Magnesium may mediate the favorable impact of whole grains on insulin sensitivity by acting as a mild calcium antagonist. Med Hypotheses 2005; 64:619-627.

19. Song Y, Manson JE, Buring JE, Liu S: Dietary magnesium intake in relation to plasma insulin levels and risk of type 2 diabetes in women. Diabetes care 2004; 27:59-65.

20. Guerrero-Romero F, Rodriguez-Moran M: Hypomagnesemia is linked to low serum HDLcholesterol irrespective of serum glucose values. J Diabetes Complicat 2000; 14:272-276.

21. Abbott RD, Ando F, Masaki KH, Tung K-H, Rodriguez BL, Petrovitch H, Yano K, Curb JD: Dietary magnesium intake and the future risk of coronary heart disease (the Honolulu Heart Program). Am J Cardiol 2003; 92:665-669.

22. Huang JH, Lu YF, Cheng FC, Lee JN, Tsai LC: Correlation of magnesium intake with metabolic parameters, depression and physical activity in elderly type 2 diabetes patients: a crosssectional study. Nutr J 2012; 11:41.

23. Bo S, Durazzo M, Guidi S, Carello M, Sacerdote C, Silli B, Rosato R, Cassader M, Gentile L, Pagano G: Dietary magnesium and fiber intakes and inflammatory and metabolic indicators in middle-aged subjects from a population-based cohort. Am J Clin Nutr 2006; 84:1062-1069.

24. Yu Y, Cai Z, Zheng J, Chen J, Zhang X, Huang XF, Li D: Serum levels of polyunsaturated fatty acids are low in Chinese men with metabolic syndrome, whereas serum levels of saturated fatty acids, zinc, and magnesium are high. Nutr Res 2012; 32:71-77.

25. Guerrero-Romero $F$, Rodriguez-Moran M: Low serum magnesium levels and metabolic syndrome. Acta Diabetol 2002; 39:209-213.

26. Simmons D, Joshi S, Shaw J: Hypomagnesaemia is associated with diabetes: Not prediabetes, obesity or the metabolic syndrome. Diabetes Res Clin Pract 2010; 87:261-266.

27. Kauffman RP, Tullar PE, Nipp RD, Castracane VD: Serum magnesium concentrations and metabolic variables in polycystic ovary syndrome. Acta Obstet Gynecol Scand 2011; 90:452458. 
28. Guo H, Lee JD, Guo M, Lu Y, Tang F, Ueda T: Status of intracellular and extracellular magnesium concentration in patients with cardiac syndrome X. Acta Cardiol 2005; 60:259263.

29. Aguilar MV, Saavedra P, Arrieta FJ, Mateos CJ, Gonzalez MJ, Meseguer I, Martinez-Para MC: Plasma mineral content in type-2 diabetic patients and their association with the metabolic syndrome. Ann Nutr Metab 2007; 51:402-406.

30. Corica F, Corsonello A, lentile R, Cucinotta D, Di Benedetto A, Perticone F, Dominguez LJ, Barbagallo M: Serum ionized magnesium levels in relation to metabolic syndrome in type 2 diabetic patients. J Am Coll Nutr 2006; 25:210-215.

31. $\mathrm{Xu} \mathrm{J,} \mathrm{Xu} \mathrm{W,} \mathrm{Yao} \mathrm{H,} \mathrm{Sun} \mathrm{W,} \mathrm{Zhou} \mathrm{Q,} \mathrm{Cai} \mathrm{L:} \mathrm{Associations} \mathrm{of} \mathrm{Serum} \mathrm{and} \mathrm{Urinary} \mathrm{Magnesium}$ with the Pre-Diabetes, Diabetes and Diabetic Complications in the Chinese Northeast Population. PloS one 2013; 8:e56750.

32. Roislien J, Van Calster B, Hjelmesaeth J: Parathyroid hormone is a plausible mediator for the metabolic syndrome in the morbidly obese: a cross-sectional study. Cardiovasc Diabetol 2011; 10:17.

33. Beydoun MA, Gary TL, Caballero BH, Lawrence RS, Cheskin LJ, Wang Y: Ethnic differences in dairy and related nutrient consumption among US adults and their association with obesity, central obesity, and the metabolic syndrome. Am J Clin Nutr 2008; 87:1914-1925.

34. Kalaitzidis R, Tsimihodimos V, Bairaktari E, Siamopoulos KC, Elisaf M: Disturbances of phosphate metabolism: another feature of metabolic syndrome. Am J Kidney Dis 2005; 45:851-858.

35. Egger M, Smith GD, Altman DG: Systematic reviews in health care : meta-analysis in context. 2nd edn. London: BMJ; 2001.

36. Song Y, Ridker PM, Manson JE, Cook NR, Buring JE, Liu S: Magnesium intake, C-reactive protein, and the prevalence of metabolic syndrome in middle-aged and older US women. Diabetes care 2005; 28:1438-1444.

37. Evangelopoulos AA, Vallianou NG, Panagiotakos DB, Georgiou A, Zacharias GA, Alevra AN, Zalokosta GJ, Vogiatzakis ED, Avgerinos PC: An inverse relationship between cumulating components of the metabolic syndrome and serum magnesium levels. Nutr Res 2008; 28:659-663.

38. Ghasemi A, Zahediasl S, Syedmoradi L, Azizi F: Low serum magnesium levels in elderly subjects with metabolic syndrome. Biol Trace Elem Res 2010; 136:18-25.

39. Guerrero-Romero F, Rodriguez-Moran M: Hypomagnesemia, oxidative stress, inflammation, and metabolic syndrome. Diabetes Metab Res Rev 2006; 22:471-476.

40. Lima Mde L, Cruz T, Rodrigues LE, Bomfim O, Melo J, Correia R, Porto M, Cedro A, Vicente E: Serum and intracellular magnesium deficiency in patients with metabolic syndrome-evidences for its relation to insulin resistance. Diabetes Res Clin Pract 2009; 83:257-262.

41. Higgins JP, Thompson SG: Quantifying heterogeneity in a meta-analysis. Stat Med 2002; 21:1539-1558.

42. Egger M, Davey Smith G, Schneider M, Minder C: Bias in meta-analysis detected by a simple, graphical test. BMJ 1997; 315:629-634.

43. Morrell JS, Lofgren IE, Burke JD, Reilly RA: Metabolic syndrome, obesity, and related risk factors among college men and women. J Am Coll Health 2012; 60:82-89.

44. Mirmiran P, Shab-Bidar S, Hosseini-Esfahani F, Asghari G, Hosseinpour-Niazi S, Azizi F: Magnesium intake and prevalence of metabolic syndrome in adults: Tehran Lipid and Glucose Study. Public Health Nutr 2012; 15:693-701.

45. Ford ES, Li C, McGuire LC, Mokdad AH, Liu S: Intake of dietary magnesium and the prevalence of the metabolic syndrome among U.S. adults. Obesity (Silver Spring) 2007; 15:1139-1146. 
46. He K, Liu K, Daviglus ML, Morris SJ, Loria CM, Van Horn L, Jacobs Jr DR, Savage PJ: Magnesium intake and incidence of metabolic syndrome among young adults. Circulation 2006; 113:1675-1682.

47. McKeown NM, Jacques PF, Zhang XL, Juan $W$, Sahyoun NR: Dietary magnesium intake is related to metabolic syndrome in older Americans. Eur J Nutr 2008; 47:210-216.

48. Song Y, Ridker PM, Manson JE, Cook NR, Buring JE, Liu S: Magnesium intake, C-reactive protein, and the prevalence of metabolic syndrome in middle-aged and older U.S. women. Diabetes Care 2005; 28:1438-1444.

49. Choi M-K, Bae Y-J: Relationship between Dietary Magnesium, Manganese, and Copper and Metabolic Syndrome Risk in Korean Adults: The Korea National Health and Nutrition Examination Survey (2007-2008). Biol Trace Elem Res 2013; 156:56-66.

50. Al-Daghri NM, Khan N, Alkharfy KM, Al-Attas OS, Alokail MS, Alfawaz HA, Alothman A, Vanhoutte PM: Selected dietary nutrients and the prevalence of metabolic syndrome in adult males and females in Saudi Arabia: a pilot study. Nutrients 2013; 5:4587-4604.

51. Noori N, Nafar M, Poorrezagholi F, Ahmadpoor P, Samadian F, Firouzan A, Einollahi B: Dietary intakes of fiber and magnesium and incidence of metabolic syndrome in first year after renal transplantation. J Ren Nutr 2010; 20:101-111.

52. He K, Liu K, Daviglus ML, Morris SJ, Loria CM, Van Horn L, Jacobs DR, Jr., Savage PJ: Magnesium intake and incidence of metabolic syndrome among young adults. Circulation 2006; 113:1675-1682.

53. Paolisso G, Sgambato S, Gambardella A, Pizza G, Tesauro P, Varricchio M, D'Onofrio F: Daily magnesium supplements improve glucose handling in elderly subjects. Am J Clin Nutr 1992; 55:1161-1167.

54. Corica F, Allegra A, lentile R, Buemi M, Corsonello A, Bonanzinga S, Macaione S, Ceruso D: Changes in plasma, erythrocyte, and platelet magnesium levels in normotensive and hypertensive obese subjects during oral glucose tolerance test. Am J Hypertens 1999; 12:128-136.

55. He K, Song Y, Belin RJ, Chen Y: Magnesium intake and the metabolic syndrome: epidemiologic evidence to date. J Cardiometab Syndr 2006; 1:351-355.

56. Song Y, He K, Levitan E, Manson J, Liu S: Effects of oral magnesium supplementation on glycaemic control in type 2 diabetes: a meta-analysis of randomized double-blind controlled trials. Diabet Med 2006; 23:1050-1056.

57. American Diabetes Association (ADA). Nutrition recommendations and principles for people with diabetes mellitus. Diabetes Care 2000; 23:S43-46.

58. Executive Summary of the Third Report of the National Cholesterol Education Program (NCEP) Expert Panel on Detection, Evaluation, and Treatment of High Blood Cholesterol in Adults (Adult Treatment Panel III). JAMA 2001; 285:2486-2497.

59. Corica F, Corsonello A, lentile R, Cucinotta D, Di Benedetto A, Perticone F, Dominguez LJ, Barbagallo $\mathrm{M}$ : Serum ionized magnesium levels in relation to metabolic syndrome in type 2 diabetic patients. J Am Coll Nutr 2006; 25:210-215.

60. Altura BT, Brust M, Bloom S, Barbour RL, Stempak JG, Altura BM: Magnesium dietary intake modulates blood lipid levels and atherogenesis. Proc Natl Acad Sci 1990; 87:1840-1844.

61. Paolisso G, Ravussin E: Intracellular magnesium and insulin resistance: results in Pima Indians and Caucasians. J Clin Endocrinol Metab 1995; 80:1382-1385.

62. Touyz R: Role of magnesium in the pathogenesis of hypertension. Mol Aspects Med 2003; 24:107-136.

63. Kandeel FR, Balon E, Scott S, Nadler JL: Magnesium deficiency and glucose metabolism in rat adipocytes. Metabolism 1996; 45:838-843.

64. Takaya J, Higashino $\mathrm{H}$, Kobayashi Y: Intracellular magnesium and insulin resistance. Magnes Res 2004; 17:126-136. 
65. Laughlin MR, Thompson D: The regulatory role for magnesium in glycolytic flux of the human erythrocyte. J Biol Chem 1996; 271:28977-28983.

66. Kazue I, Terakazu K, Motoomi N: The effects of nigh oral magnesium supplementation on blood pressure, serum lipids and related variables in apparently healthy Japanesse subjects. Br J Nutr 1997; 78:737-750.

67. Rayssiguier Y, Noe L, Etienne J, Gueux E, Cardot P, Mazur A: Effect of magnesium deficiency on post-heparin lipase activity and tissue lipoprotein lipase in the rat. Lipids 1991; 26:182186.

68. Drenick E: The influence of ingestion of calcium and other soap-forming substances on fecal fat. Gastroenterology 1961; 41:242-244.

69. Elin RJ: Assessment of magnesium status for diagnosis and therapy. Magnes Res 2010; 23:194-198.

70. Topf JM, Murray PT: Hypomagnesemia and hypermagnesemia. Rev Endocr Metab Disord 2003; 4:195-206.

71. Bardicef M, Bardicef O, Sorokin Y, Altura BM, Altura BT, Cotton DB, Resnick LM: Extracellular and intracellular magnesium depletion in pregnancy and gestational diabetes. Am J Obstet Gynecol 1995; 172:1009-1013.

72. Jahnen-Dechent W, Ketteler M: Magnesium basics. Clin Kidney J 2012; 5:i3-i14. 
Table 1: Characteristics of studies investigating the association between dietary Mg intake and metabolic syndrome

\begin{tabular}{|c|c|c|c|c|c|c|c|}
\hline Author, year (country) & $\begin{array}{l}\text { Metabolic } \\
\text { syndrome } \\
\text { definition }\end{array}$ & Study design & $\begin{array}{l}\text { Sample } \\
\text { size }\end{array}$ & $\begin{array}{c}\text { Age } \\
\text { range } \\
\text { (years) } \\
\text { Or mean-SD }\end{array}$ & sex & Adjusted OR or RR & Adjusted variables \\
\hline Bo et al, 2006 (Italy) [23] & (ATP III) & $\begin{array}{c}\text { cross- } \\
\text { sectional }\end{array}$ & 1658 & $64-45$ & both & $1.03(0.62,1.70)$ & $\begin{array}{l}\text { age, sex, BMI, smoking, alcohol, } \\
\text { Physical activity, calories, fat, fiber }\end{array}$ \\
\hline Ford et al, 2007 (US) [45] & (ATP III) & $\begin{array}{c}\text { cross- } \\
\text { sectional }\end{array}$ & 7669 & $20<$ & both & $0.56(0.34,0.92)$ & $\begin{array}{l}\text { age, sex, race, education, smoking,CRP, } \\
\text { alcohol, Ph A, Family history coronary } \\
\text { disease, vit and sup intake, diabetes } \\
\text { history, fat, CHO, fiber, total energy }\end{array}$ \\
\hline He et al, 2006 (US) [52] & (ATP III) & cohort & 4637 & $30-18$ & both & $0.63(0.47-0.84)$ & $\begin{array}{l}\text { age, sex, race, education, smoking, Ph A, } \\
\text { FH diabetee, alcohol, BMI, fiber, PUFA, } \\
\text { SFA, CHO,total energy . model4: model } \\
3 \text { plus MetS components minus BMI }\end{array}$ \\
\hline $\begin{array}{c}\text { Song et al, } 2005 \text { (US) } \\
{[36]}\end{array}$ & (ATP III) & $\begin{array}{c}\text { cross- } \\
\text { sectional }\end{array}$ & 11686 & $45<$ & female & $0.65(0.52-0.83)$ & $\begin{array}{l}\text { age, calorie, smoking, } \mathrm{PhA} \text {, alcohol, FH } \\
\text { myocardial infarction, fat, cholestrol, } \\
\text { folate, glycemic load }\end{array}$ \\
\hline $\begin{array}{c}\text { Noori et al,2010 (Iran) } \\
\text { [51] }\end{array}$ & (ATP III) & cohort & 160 & $18<$ & both & $1.73(0.38-7.85)$ & $\begin{array}{c}\text { age, sex, smoking, PhA, Dialysis mode, } \\
\text { dose of stroid,FH diabetes and stroke, } \\
\text { calorie, BMI, fiber }\end{array}$ \\
\hline $\begin{array}{l}\text { McKeown et al, } 2008 \\
\text { (US) [47] }\end{array}$ & (ATP III) & $\begin{array}{c}\text { cross- } \\
\text { sectional }\end{array}$ & 535 & $60<$ & both & $0.36(0.19,0.69)$ & $\begin{array}{l}\text { age, sex, race, education, marital status, } \\
\text { smoking, alcohol, PhA, BMI, calorie, } \\
\text { SFA, lipid medication, BP medication } \\
\text { except for model with BP }\end{array}$ \\
\hline $\begin{array}{c}\text { Huang et al,2012 (Taiwan) } \\
\text { [22] }\end{array}$ & (ATP III) & $\begin{array}{c}\text { cross- } \\
\text { sectional }\end{array}$ & 210 & $65<$ & both & $0.49(0.17-1.43)$ & - \\
\hline
\end{tabular}




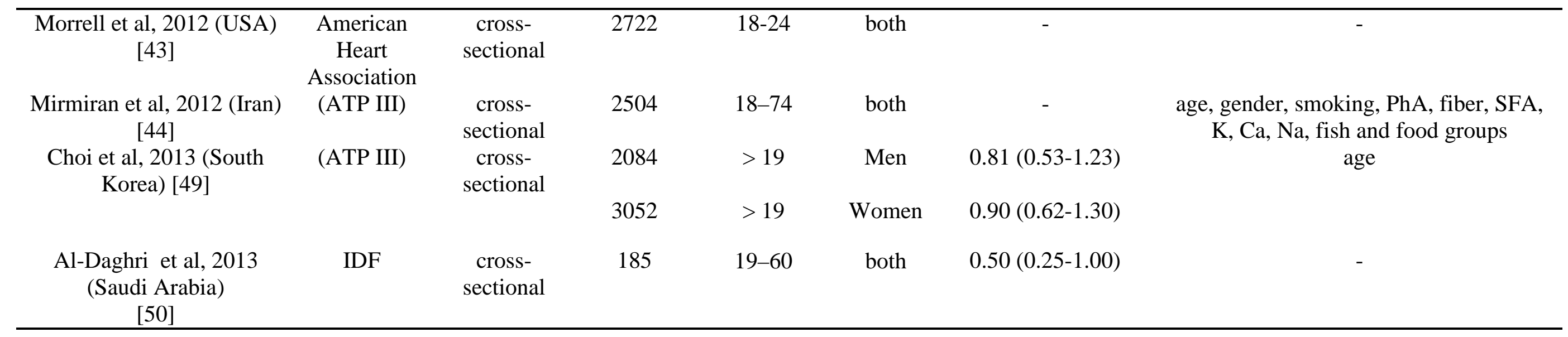


Table 2: Characteristics of studies investigating the association between serum Mg level and metabolic syndrome.

\begin{tabular}{|c|c|c|c|c|c|c|c|c|c|}
\hline Author & $\begin{array}{l}\text { Metabolic } \\
\text { syndrome } \\
\text { definition }\end{array}$ & Study design & $\begin{array}{l}\text { Sam } \\
\text { ple } \\
\text { size }\end{array}$ & $\begin{array}{l}\text { Age } \\
\text { range } \\
\text { case }\end{array}$ & $\begin{array}{l}\text { Age } \\
\text { range } \\
\text { control }\end{array}$ & sex & $\begin{array}{c}\text { No MS } \\
\text { Serum Mg } \\
\text { mean } \pm \text { SD }\end{array}$ & $\begin{array}{c}\text { MS } \\
\text { Serum Mg } \\
\text { mean+SD }\end{array}$ & Adjusted variable \\
\hline $\begin{array}{l}\text { Evangelopoulos } \\
\text { et al, 2008 } \\
\text { (Athens ) [37] }\end{array}$ & IDF & $\begin{array}{c}\text { Cross } \\
\text { sectional }\end{array}$ & 117 & 67.0 & 65.0 & both & $\begin{array}{c}1.99 \pm 0.24 \\
\mathrm{~N}=35\end{array}$ & $\begin{array}{c}1.83 \pm 0.23 \\
\mathrm{~N}=82\end{array}$ & - \\
\hline $\begin{array}{l}\text { Ghasemi et al, } \\
2010 \text { (Iran) [38] }\end{array}$ & ATP III & $\begin{array}{c}\text { Cross } \\
\text { sectional }\end{array}$ & 137 & $60-90$ & $60-90$ & both & $\begin{array}{c}2.16 \pm 0.03 \\
(n=77)\end{array}$ & $\begin{array}{c}2.08 \pm 0.03 \\
(n=60)\end{array}$ & $\begin{array}{c}\text { Sex- and creatinine, high } \\
\text { TG, high WC, hypertension, } \\
\text { and low HDL-C, } \\
\text { hyperglycemia and diabetes }\end{array}$ \\
\hline $\begin{array}{c}\text { Guerrero- } \\
\text { Romero et al, } \\
2002 \text { (Mexico) } \\
\text { [25] }\end{array}$ & ATP III & Case control & 576 & 42.3 & 41.5 & both & $\begin{array}{c}2.20 \pm 0.20 \\
(n=384)\end{array}$ & $\begin{array}{c}1.80 \pm 0.30 \\
(n=192)\end{array}$ & - \\
\hline $\begin{array}{c}\text { Guerrero- } \\
\text { Romero et al, } \\
2006 \text { (Mexico) } \\
\text { [39] }\end{array}$ & ATP III & Case-control & 441 & 44.0 & 43.0 & both & $\begin{array}{l}2.1 \pm 0.3 \\
(n=294)\end{array}$ & $\begin{array}{l}1.8 \pm 0.4 \\
(n=147)\end{array}$ & - \\
\hline $\begin{array}{c}\text { Kalaitzidis et al, } \\
2005 \text { (Greece) } \\
\text { [34] }\end{array}$ & ATP III & $\begin{array}{c}\text { Cross } \\
\text { sectional }\end{array}$ & 255 & 48.8 & 48.7 & both & $\begin{array}{c}2.04 \pm 0.36 \\
(n=191)\end{array}$ & $\begin{array}{c}1.92 \pm 0.36 \\
(n=64)\end{array}$ & - \\
\hline $\begin{array}{l}\text { Simmons et al, } \\
2010 \text { (Australia) } \\
\text { [26] }\end{array}$ & ATPIII & $\begin{array}{c}\text { Cross } \\
\text { sectional }\end{array}$ & 1453 & 53 & 53 & & $\begin{array}{c}2.02 \pm 0.14 \\
(n=1168)\end{array}$ & $\begin{array}{c}2.02 \pm 0.17 \\
(n=363)\end{array}$ & - \\
\hline $\begin{array}{c}\text { Yu et al, } 2012 \\
\text { (China) [24] }\end{array}$ & $\begin{array}{l}\text { Chinese } \\
\text { Diabetes } \\
\text { Society's }\end{array}$ & $\begin{array}{c}\text { Cross } \\
\text { sectional }\end{array}$ & 379 & $57-24$ & $57-24$ & male & $\begin{array}{c}1.93 \pm 0.28 \\
(\mathrm{n}=149)\end{array}$ & $\begin{array}{c}2.09 \pm 0.28 \\
\quad(n=52)\end{array}$ & - \\
\hline $\begin{array}{c}\text { Lima et al, } 2009 \\
\text { (Brazil) [40] }\end{array}$ & IDF & $\begin{array}{c}\text { cross } \\
\text { sectional } \\
\end{array}$ & 129 & $\begin{array}{c}45.7 \pm 11 . \\
8 \\
\end{array}$ & $\begin{array}{c}45.7 \pm 1 \\
1.8 \\
\end{array}$ & both & $\begin{array}{c}2.43 \pm 0.43 \\
(\mathrm{n}=57)\end{array}$ & $\begin{array}{c}1.80 \pm 0.18 \\
(\mathrm{n}=72)\end{array}$ & - \\
\hline
\end{tabular}




\section{Legends of Figures}

Figure 1. The Study selection process.

Figure 2. Meta-analyses of studies examining dietary magnesium intake and MetS.

Figure 3. Meta-analyses of studies examining dietary magnesium intake and MetS after removing study done by McKeown et al [47] which used BMI higher than 31 $\mathrm{kg} / \mathrm{m} 2$ for men and $27 \mathrm{~kg} / \mathrm{m} 2$ for women as an index for abdominal obesity

Figure 4. Meta-analyses of studies examining serum magnesium level and MetS.

Figure 5. Meta-analyses of studies examining serum magnesium level and MetS after removing two had used IDF [37, 40], one used Chinese Diabetes Society's [24] criteria to define MetS and a study done by Guerrero-Romero [25] which had excluded individuals with hypertension and diabetes from the study population.

Figure 6. A) Begg's funnel plot (with pseudo 95\% confidence interval) in Log OR versus standard error of Log OR for studies that reported the OR of Mg intake. B) Begg's funnel plot (with pseudo 95\% confidence interval) in mean difference (MD) versus standard error of mean difference for studies that reported the serum Mg. 
Figure 1.

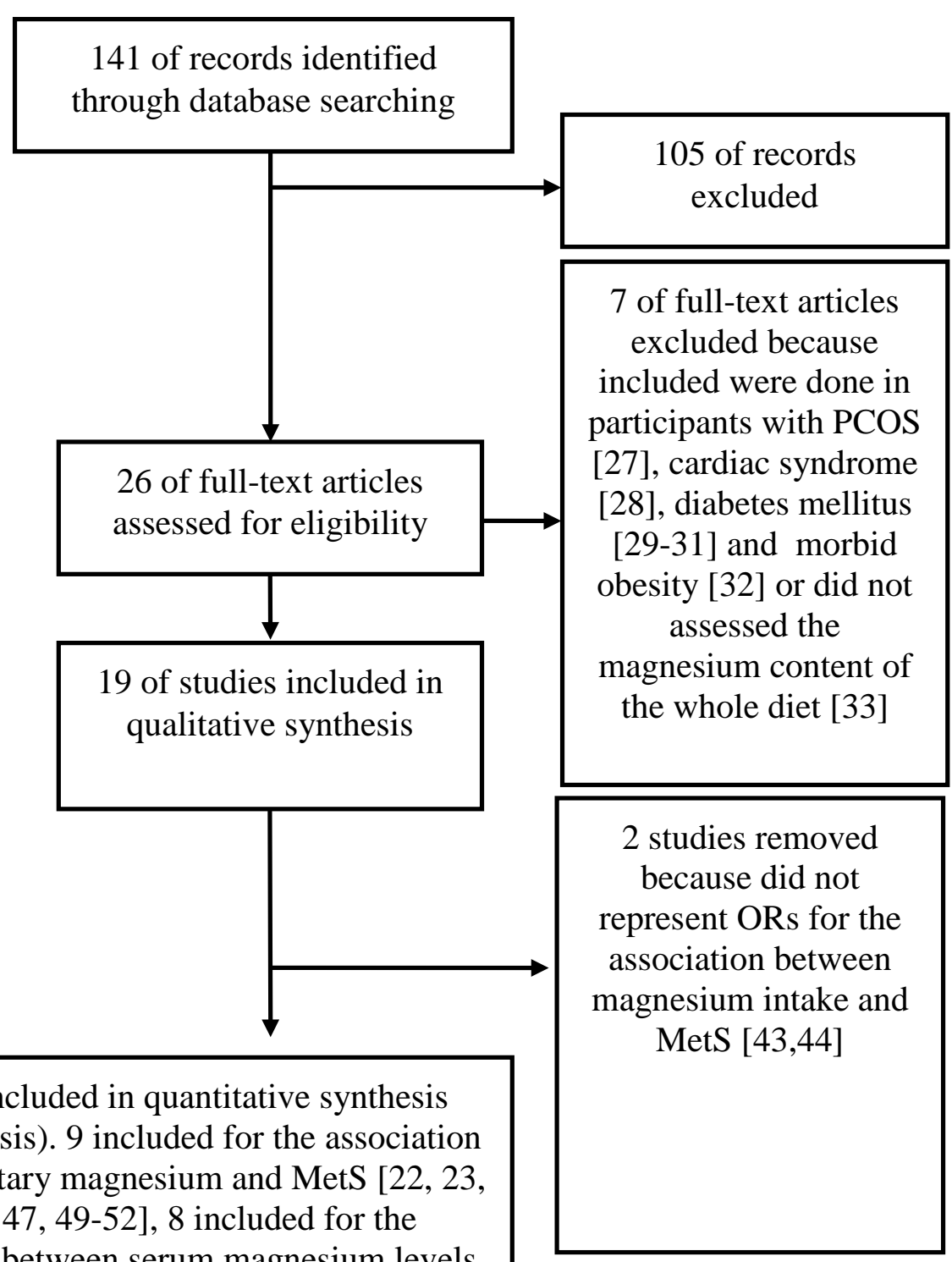

Studies included in quantitative synthesis (meta-analysis). 9 included for the association between dietary magnesium and MetS [22, 23, 36 , 45, 47, 49-52], 8 included for the association between serum magnesium levels and MetS [24-26, 34, 37-40] 
Figure 2.

Study (year)

Song et al. (2005)

Bo et al. (2006)

He et al. (2006)

Ford et al. (2007)

McKe et al. (2008)

Noori et al. (2010)

Huang et al. (2012)

Al-Daghri et al. (2013)

Choi and Bae (Men) (2013)

Choi and Bae (Women) (2013)

Overall
Odds Ratio (95\% CI) Weight (\%)

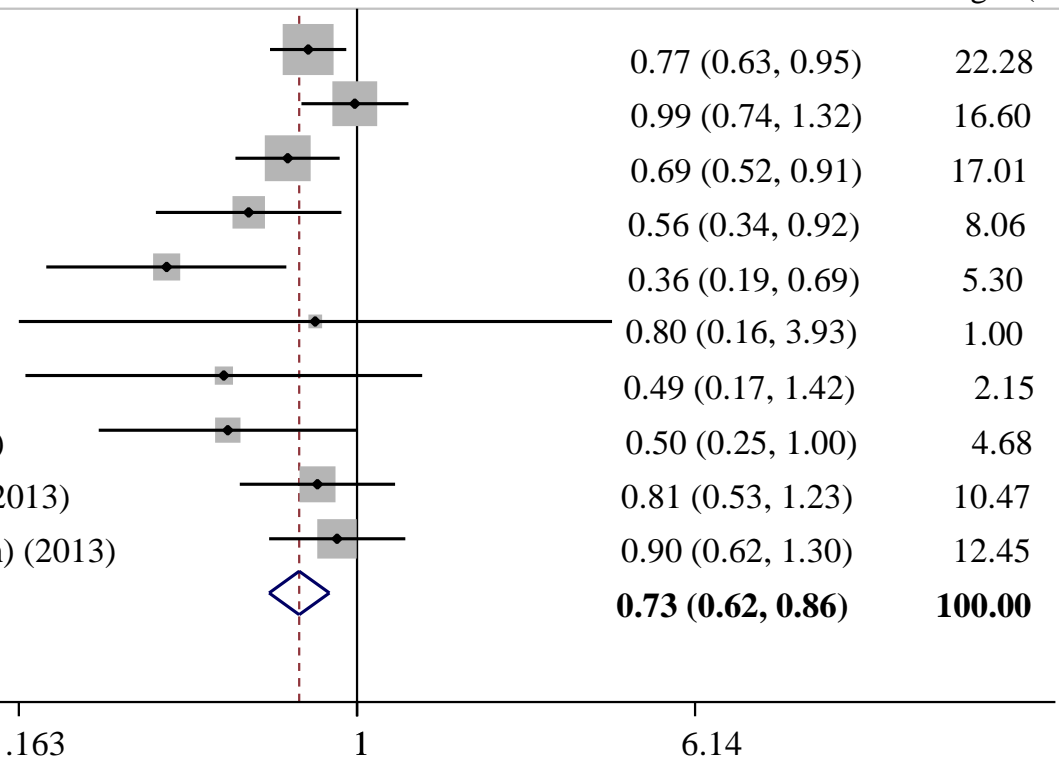


Figure. 3.

Study(year)

Song et al. (2005)

Bo et al. (2006)

He et al. (2006)

Ford et al. (2007)

Noori et al. (2010)

Huang et al. (2012)

Al-Daghri et al. (2013)

Choi and Bae (Men) (2013)

Choi and Bae (Women) (2013)

Overall
Odds Ratio (95\% CI) Weight (\%)

$\begin{array}{lr}0.77(0.63,0.95) & 33.99 \\ 0.99(0.74,1.32) & 17.62 \\ 0.69(0.52,0.91) & 18.46 \\ 0.56(0.34,0.92) & 5.87 \\ 0.80(0.16,3.93) & 0.58 \\ 0.49(0.17,1.42) & 1.29 \\ 0.50(0.25,1.00) & 3.03 \\ 0.81(0.53,1.23) & 8.36 \\ 0.90(0.62,1.30) & 10.81 \\ \mathbf{0 . 7 8}(\mathbf{0 . 6 9 , 0 . 8 8}) & \mathbf{1 0 0 . 0 0}\end{array}$

6.14 
Figure.4.

Study (year)

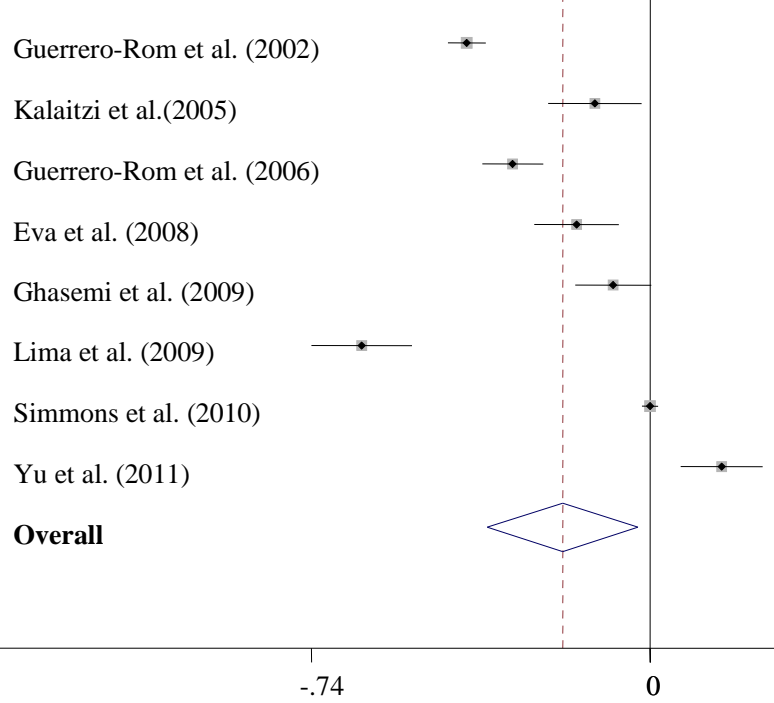

Mean Difference (95\% CI) Weight (\%)

$\begin{array}{ll}-0.40(-0.44,-0.36) & 12.78 \\ -0.12(-0.22,-0.02) & 12.28 \\ -0.30(-0.37,-0.23) & 12.62 \\ -0.16(-0.25,-0.07) & 12.38 \\ -0.08(-0.16,0.00) & 12.47 \\ -0.63(-0.74,-0.52) & 12.19 \\ 0.00(-0.02,0.02) & 12.87 \\ 0.16(0.07,0.25) & 12.41 \\ \mathbf{- 0 . 1 9}(-\mathbf{- 0 . 3 6 , - 0 . 0 3 )} & \mathbf{1 0 0 . 0 0}\end{array}$


figure 5.

Study

Kalaitzi et al. (2005)
Guerrero-Rom et al. (2006
Ghasemi et al. (2009)
Simmons et al. (2010)
Overall

NOTE: Weights are from random effects analysis
Mean Difference (95\% CI) Weight (\%)

$\begin{array}{ll}-0.12(-0.22,-0.02) & 23.73 \\ -0.30(-0.37,-0.23) & 25.25 \\ -0.08(-0.16,0.00) & 24.58 \\ 0.00(-0.02,0.02) & 26.43 \\ & \\ \mathbf{- 0 . 1 2}(\mathbf{- 0 . 2 8}, \mathbf{0 . 0 3}) & \mathbf{1 0 0 . 0 0}\end{array}$

$-.367$

.367 
Figure. 6.A)

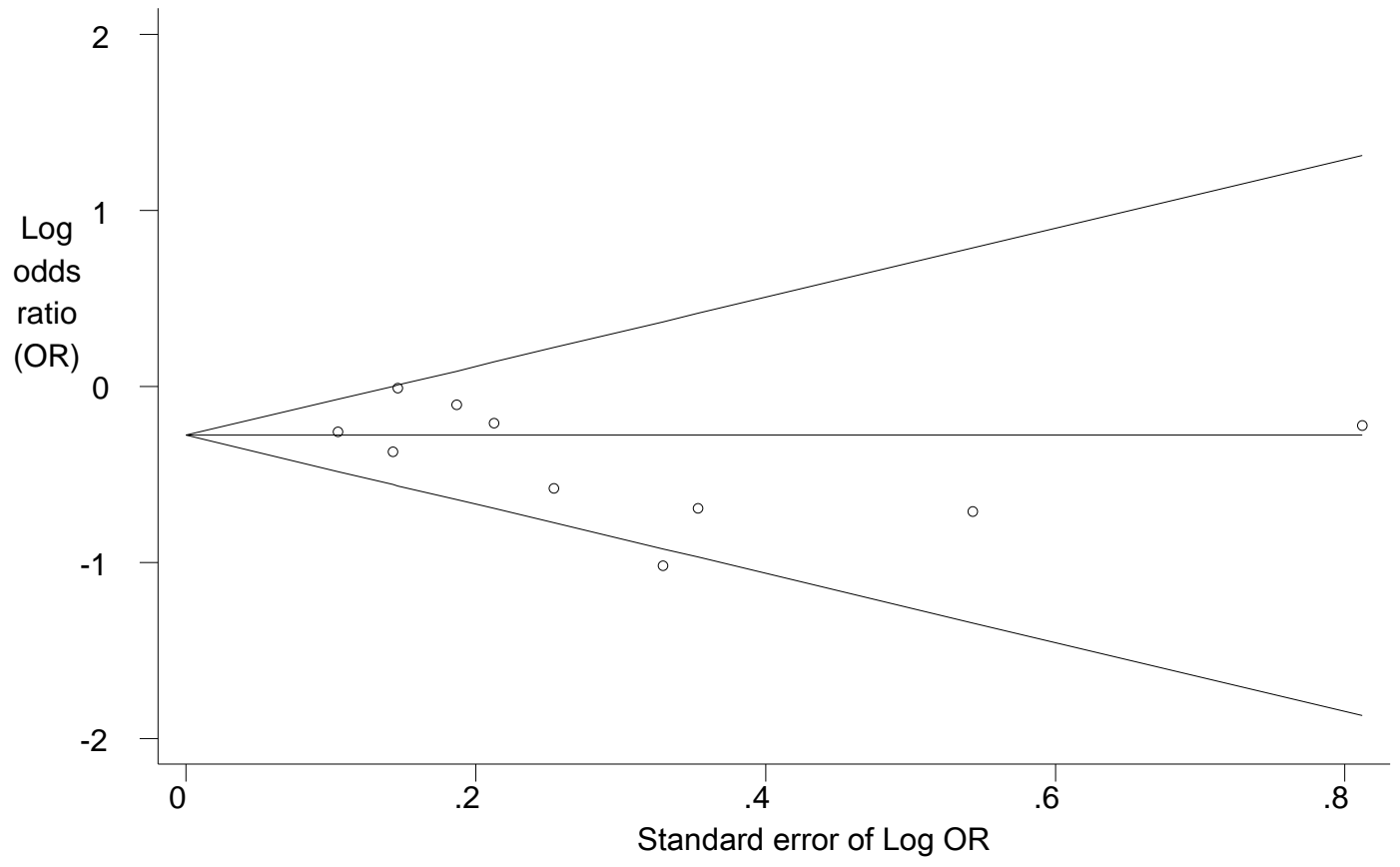

Figure.6.B)

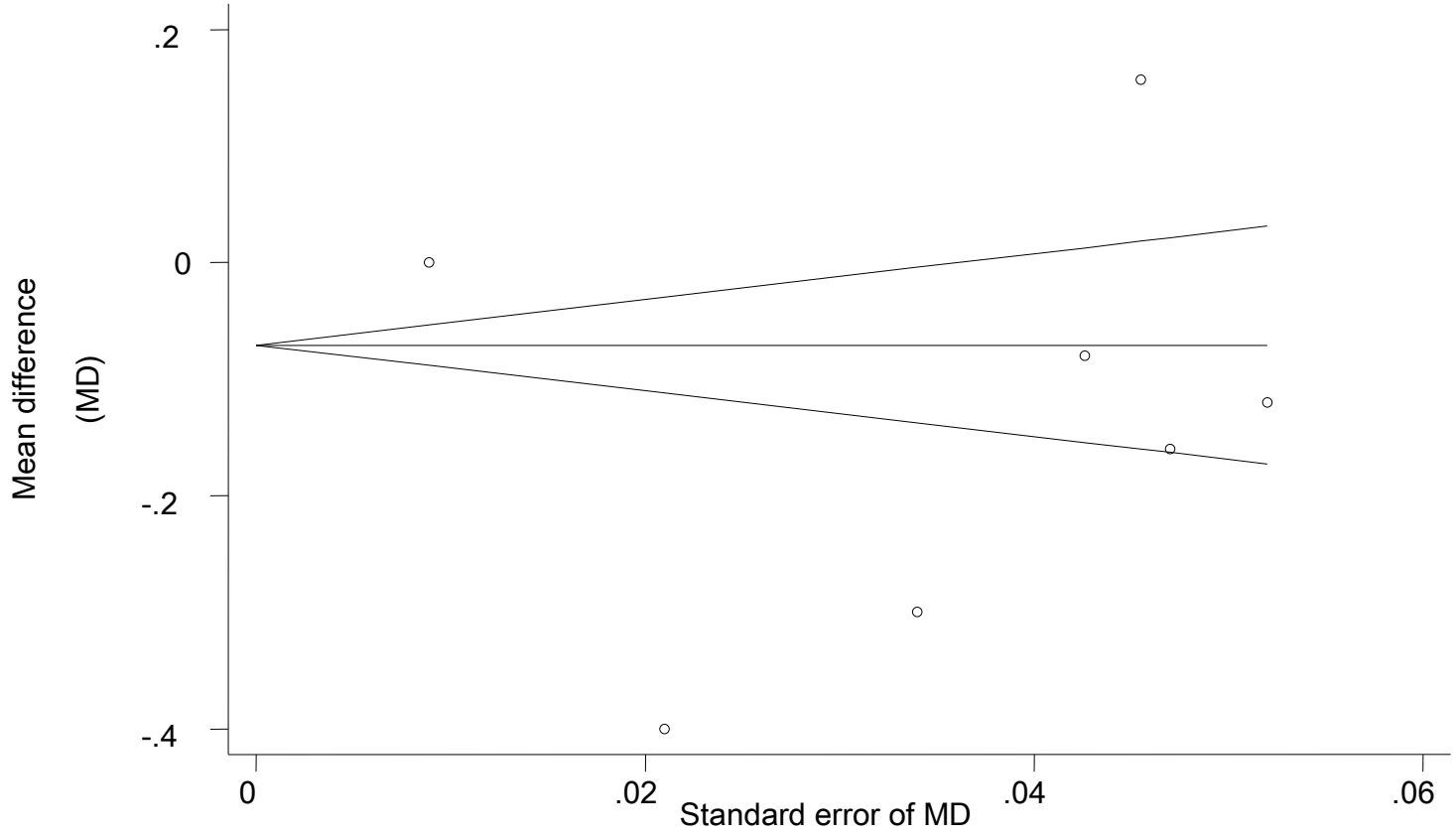

